\title{
PRAKTIK GHARAR PADA HUBUNGAN BISNIS UMKM-EKSPORTIR FURNITUR DI JEPARA ${ }^{1)}$
}

\author{
Achmad Hiji Lidinillah \\ Mahasiswa Program Studi S1 Ekonomi Islam - Fakultas Ekonomi dan Bisnis - Universitas \\ Airlangga \\ Email : hiji.lidinillah@gmail.com \\ Imron Mawardi \\ Departemen Ekonomi Syariah - Fakultas Ekonomi dan Bisnis - Universitas Airlangga \\ Email : imron.mawardi@gmail.com
}

\begin{abstract}
:
This study aims to determine the type of gharar practiced in cooperation between Small and medium industry exporters of furniture to the furniture in Jepara district.

This study used a qualitative descriptive approach with a case study strategy. Determinating techniques for informants in this study using snowball sampling. Data collected through interviews with research subjects and direct observation of the research object. The analysis technique used is descriptive analysis by using the method of data analysis and describes the results of interviews and direct observation.

The results of this study indicate that gharar is practiced in the cooperation between the Small and medium industry with the company exporting furniture is unclear at the end of the time limit on credit payments by companies exporting furniture to the Small and medium industry as suppliers of goods to the company.
\end{abstract}

Keywords: Gharar, Small and medium industry, cooperation.

\section{PENDAHULUAN}

Syariah (Islam) sebagai ad-din, menurut M. Hidayat (2010:9), adalah agama yang universal dan komprehensif. Universal berarti bahwa Islam diperuntukkan bagi seluruh umat manusia di muka bumi dan dapat diterapkan dalam setiap waktu dan tempat sampai akhir zaman. Komprehensif berarti bahwa Islam mempunyai ajaran yang lengkap dan sempurna (syumul). Kesempurnaan ajaran Islam mengatur seluruh aspek kehidupan manusia dan tidak hanya aspek spiritual (ibadah murni), tetapi juga aspek muamalah yang meliputi ekonomi, sosial, politik, hukum, dan sebagainya.

Allah berfirman dalam surat alAn'am ayat 38

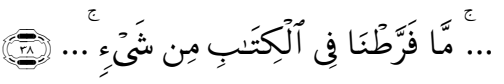

Mā farrațnā fil kitābi min syai-in

Artinya: ...Tiadalah Kami alpakan sesuatupun dalam Al-Kitab...

Dari ayat diatas maka tidak tepat jika Islam dianggap hanya sebuah aturan ritual, apalagi banyak yang mengatakan masalah keduniawian seperti halnya berbisnis dan pembagunan tidak ada sangkut pautnya dengan Islam. Pandangan seperti ini disebabkan umat Islam (atau umat lain) tidak memahami ajaran Islam secara utuh, padahal semua urusan ibadah dan muamalah manusia sudah diatur di dalamnya.

Industri furnitur dan kerajinan merupakan salah satu sektor strategis yang dapat memberikan kontribusi signifikan terhadap pertumbuhan perekonomian nasional, khususnya dalam

1) Jurnal ini merupakan skripsi dari Ahmad Hijri Lidinillah, NIM : 041014032. 
perolehan devisa negara dan penyerapan tenaga kerja. Menurut data kemenperin (2013), Indonesia memiliki lebih dari 4.000 UKM di industri mebel, dan pasar domestik tumbuh sangat cepat. Sementara, penjualan domestik untuk furnitur dan kerajinan diperkirakan mencapai lebih dari US $\$ 700$ juta per tahun, sementara ekspor furnitur mencapai US \$1,7 miliar pada tahun 2013 . Jumlah tenaga kerja yang diserap mencapai 432 ribu orang tenaga kerja, sedangkan industri kayu pertukangan menyerap lebih dari 286 ribu tenaga kerja. (http://www.antaranews.com/berita/4157 78/kemenperin-tingkatkan-ekspor-furniturlewat-pameran-internasional, diakses 14 Juni 2014).

Jepara adalah salah satu kabupaten di Jawa Tengah yang mengandalkan sektor industri furnitur sebagai mata pencaharian utama penduduknya, menurut BPS kabupaten Jepara 2012 sebanyak 54\% dari seluruh jumlah angkatan kerja kabupaten Jepara bekerja pada indutri furnitur, sisanya $23,3 \%$ pada industri manufaktur lain, 11,9\% pada sektor jasa dan $10,8 \%$ pada sektor pertanian dan kelautan. (jeparakab.bps.go.id, diakses 14 Juni 2014).

Permintaan pasar untuk produk furnitur Jepara cukup besar, pada tahun 2012 tercatat perolehan 100,33 juta dollar Amerika dengan 103 negara tujuan. Industri furnitur Jepara didominasi oleh usaha kecil menengah dengan jumlah unit usaha yang terus bertambah di tiap tahunnya, adapun data jumlah UKM industri furnitur yang tersebar di seluruh kecamatan di kabupaten Jepara adalah sebagai berikut:

Tabel 1.

Indikator Perkembangan Usaha Kabupaten Jepara

\begin{tabular}{|c|c|c|c|}
\hline Tenaga Kerja (orang) & 51934 & 52443 & 53334 \\
\hline 1. Jumlah Unit Usaha & 3916 & 3955 & 4022 \\
\hline $\begin{array}{ll}\text { Volume } & \text { Produksi } \\
\text { (Buah) } & \end{array}$ & 2.734 .256 & 2.761 .460 & 2.808 .606 \\
\hline Nilai Investasi $(000)$ & Rp. 164.506.965 & Rp. 166.145 .279 & Rp. 168.969 .748 \\
\hline 1. Nilai Produksi $(000)$ & $\begin{array}{l}\text { Rp. } \\
1.230 .416 .000\end{array}$ & $\begin{array}{l}\text { Rp. } \\
1.242 .669 .859\end{array}$ & $\begin{array}{l}\text { Rp. } \\
1.263 .795 .246\end{array}$ \\
\hline
\end{tabular}

Sumber : Disperindag Jepara, diolah 2011

Dalam kesehariannya, menurut Sulasmi dan David pada saat observasi, para pengusaha UMKM industri furnitur di kabupaten Jepara bisa dikatakan tidak memproduksi untuk konsumen akhir, tetapi para pengusaha furnitur kecil ini menerima pesanan beberapa set dari perusahaan eksportir yang mendapat pesanan dari negara pemesan atau menerima pesanan dari pemilik showroom kerajinan kayu untuk dipajang dan dipasarkan di showroom mereka.

Tetapi setelah mengirimkan pesanan ke perusahaan eksportir dan pemilik showroom pengusaha furnitur kecil tidak mendapat pembayaran kontan dari perusahaan eksportir dan pemilik showroom, dengan alasan produk furnitur dari pengusaha furnitur mikro harus diperiksa kadar air dan diperiksa apakah ada cacat pada produk furnitur yang mereka setorkan. Pada saat penyetoran pengusaha furnitur kecil sebagai produsen 
hanya menerima uang muka dan surat tagih yang tidak ditentukan kapan sisa pembayaran dilunasi.

Dalam Harian Suara Merdeka (online) Hadi Priyanto, Kabag Inkom Sekretariat Daerah Kabupaten Jepara mengatakan bahwa Tak banyak pengusaha yang bersedia memberi uang muka dan membayar tunai barangbarang yang dipesannya ketika sudah jadi. Kadang sampai 1-2 bulan baru dilunasi, ketika barang-barang yang dikerjakan telah dikirim ke luar negeri atau telah terjual.

(http://www.suaramerdeka.com/v1/index. $\mathrm{php} / \mathrm{read} /$ cetak/2008/02/27/2661/Menya ngga-Tiang-yang-Mulai-Goyah, diakses 14 Juni 2014).

Menurut Sulasmi pada saat observasi, ada juga produsen yang sudah mengirimkan beberapa kali dan menagihkan beberapa surat tagih pada perusahaan eksportir, mereka mendapatkan pembayaran sebagian dari nilai yang tertera pada surat tagih itu, tidak kunjung mendapat pelunasan. Tentu ini akan menyulitkan pihak pengusaha furnitur kecil sebagai pemasok barang pada perusahaan eksportir. Karena tidak kunjung menerima hasil usahanya.

Fenomena pada hubungan usaha UMKM-eksportir furnitur ini sangat disayangkan, karena seharusnya Kabupaten Jepara menjadi panutan daerah lain dalam pengembangan dan kesejahteraan pelaku industri furnitur mengingat sejarah perkembangan perniagaan furnitur yang maju pada masa lampau.

Gharar sendiri menurut Ibn Taimiyah mempunyai banyak pengertian, antara lain: pertama, sesuatu yang tersembunyi baik akibatnya, rahasianya, atau segala sesuatunya. kedua, sesuatu yang tidak jelas antara mulus atau cacatnya sehingga dengan demikian maksud dari diadakannya akad bisa tercapai atau tidak.

$$
\text { Menurut Mustafa E. N dkk }
$$
(2007:26), manusia diberi kebebasan oleh Allah dalam perekonomian, baik secara individu ataupun kolektif untuk mencapai tujuan. Namun kebebasan tersebut tidak boleh melanggar aturan-aturan yang telah digariskan oleh Allah SWT. Dengan demikian kebebasan tersebut tidak bersifat mutlak. Allah SWT membatasi perilaku manusia dalam perekonomian dengan firmannya surat Al-Baqarah ayat 188:

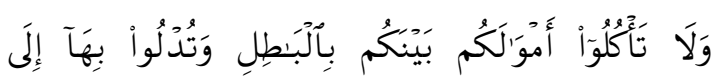

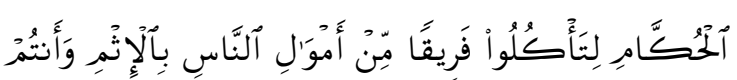

$$
\text { تَعَلَمُونَ }
$$

Walā ta'kulū amwālakum bainakum bi' lbāthili wa tudlū bihā ilā'l- ḥukkāmi lita'kulū faiilqan min amwāli'n-nāsi bi'l-itsmi wa antum ta'lamūna

188. Dan janganlah sebahagian kamu memakan harta sebahagian yang lain di antara kamu dengan jalan yang bathil dan (janganlah) kamu membawa (urusan) harta itu kepada hakim, supaya 
kamu dapat memakan sebahagian daripada harta benda orang lain itu dengan (jalan berbuat) dosa, padahal kamu Mengetahui.

\section{Rumusan Masalah}

Berdasarkan uraian latar belakang masalah, maka penulis akan membahas rumusan masalah dalam penelitian ini adalah:

1. Apa jenis gharar yang terdapat pada hubungan bisnis antara pelaku UMKM -eksportir furnitur?

2. Bagaimana pendapat ulama tentang kerjasama berunsur gharar tersebut?

\section{Tujuan Penelitian}

Beredasarkan perumusan masalah sebelumnya, maka tujuan penelitian ini adalah untuk mengetahui praktik dan jenis gharar pada hubungan usaha pengusaha UMKM-eksportir industri furnitur dengan pihak eksportir di kabupaten Jepara.

\section{Pengembangan Proposisi}

Menurut Ghazaly dkk (2010:50) kata akad berasal dari bahasa Arab al'aqd yang secara etimologi berarti perikatan, perjanjian, permufakatan (ittifaq). Secara teminologi figh, akad didefinisikan dengan:

"Pertalian ijab (pernyataan melakukan ikatan) dan qabul (pernyataan penerimaan ikatan) sesuai dengan kehendak syariat yang berpengaruh pada objek perikatan".

\section{Rukun dan Syarat Akad}

Pemaparan Sehendi yang dikutip oleh Ghazali dkk mengena rukun-rukun akad adalah sebagai berikut: a) 'Aqid, adalah orang yang berakad; terkadang masingmasing pihak terdiri dari satu orang, terkadang terdiri dari beberapa orang. Misalnya, penjual dan pembeli beras di pasar biasanya masing-masing pihak satu orang; ahli waris sepakat untuk memberikan sesuatu kepada pihak yang lain ng terdiri dari beberapa orang. Seseorang yang berakad terkadang orang memiliki hak ('aqid ashli) dan merupakan wakil dari yang memiliki hak.

b) Ma'qud alaih, ialah benda-benda yang diakadkan, seperti bendabenda yang dijual dalam akad jual beli, dalah akad hibah (pemberian), gadai, utang yang dijamin seseorang dalam akad kafalah.

c) Maudhu' a-'aqd, yaitu tujuan atau maksud pokok mengadakan akad. Berbeda akad maka berbedalah tujuan pokok akad. Dalam akad jual beli misalnya, tujuan pokoknya yaitu memindahkan barang dari penjual kepada pembeli dengan diberi ganti. Tujuan pokok hibah yaitu memindahkan barang dari pemberi kepada yang diberi untuk dimilikinya tanpa pengganti ('iwadh). Tujuan pook akad ijarah yaitu memberikan manfaat dengan adanya pengganti ('iwadh). Tujuan pokok akad i'arah yaitu memberikan mafaat bagi 
seseorang kepada yang lain tanpa pengganti.

Shighat al-'aqd ialah ijab qabul. ljab ialah permulaan penjelasan yang keluar dari salah seorang yang berakad sebagaigambaran kehendaknya dalam mengadakan akad. Adapun qabul adalah perkataan yang keluar dari pihak yang berakad pula yang diucapkan setelah adanya ijab.

Hasbi Ash Shiddiqy (dalam Ghazali dkk, 2010:54) memaparkan bahwa setiap akad mempunyai syarat yang ditentukan syara' yang wajib disempurnakan. Syaratsyarat terjadinya akad ada dua macam:

a) Syarat-syarat yang bersiat umum, yaitu syarat-syarat yang wajib sempurna wujudnya dalam berbagai akad. Syarat-syarat umum yang harus dipenuhi dalam berbagai macam akad sebagai berikut:

1) Kedua orang yang melakukan akad cakap bertindak (ahli). Tidak sah akad orang yang tidak cakap bertindak, seperti orang gila, orang yang berada di bawah pengampuan (mahjur), dan karena boros.

2) Yang dijadikan objek akad dapat menerima hukumnya.

3) Akad itu sudah diizinkan oleh syara', dilakukan oleh orang yang mempunyai hak untuk melakukannya, walaupun dia bukan 'aqid yang mempunyai barang.
4) Janganlah akad itu adalah akad yang dilarang oleh syara', seperti jual beli mulamasah (saling merasakan).

5) Akad dapat memberikan faedah sehingga tidaklah sah bila rahn (gadai) dianggap sebagai imbangan amanah (kepercayaan).

6) ljab itu berjalan terus, tidak dicabut sebelum terjadi qabul. Maka apabila orang yang berijab menarik kembali ijabnya sebelum qabul maka batallah ijabnya

7) ljab dan qabul mesti besambung, sehingga apabila orang yang berijab telah berijab sebelum adanya qabul, maka ijab tersebut menjadi batal.

b) Syarat-syarat yang bersifat khusus, yaitu syarat-syarat yang wujudnya wajib ada dalam sebagian akad. syarat khusus ini dapat juga disebut syarat idhafi (tambahan) yang harus ada di samping syaratsyarat yang umum, seperti syarat adanya saksi dalam pernikahan.

\section{Macam-Macam Akad}

Wahbah al-Zuhaily (dalam Ghazali, 2010:55) menulis bahwa para ulama figh mengemukakan bahwa akad itu dapat dibagi dilihat dari beberapa segi. Jika dilihat dari segi keabsahannya menurut syara', akad terbagi dua, yaitu: 
a. Akad Sahih, ialah akad akad yang telah memenuhi rukun-rukun dan syarat-syaratnya. Hukum dari akad sahih ini adalah berlakunya seluruh akibat hukum yang ditimbulkan akad itu dan mengikat pada pihak-pihak yang berakad.

b. Akad ghairu sahih, yaitu akad yang terdapat kekurangan pada rukun atau syarat-syaratnya, sehingga seluruh akibat hukum akad itu tidak berlaku dan tidak mengikat pihak-pihak yang berakad. Kemudian ulama Hanafiyah membagi akad yang tidak shahih ini menjadi dua macam, yaitu akad bathil dan fasid.

\section{Pengertian Gharar}

Arti kata gharar adalah resiko, tipuan dan menjatuhkan diri atau harta ke jurang kebinasaan. Secara istilahiyyah, diungkapkan oleh Ibnu Taimiyah (2002:275) yang mengatakan bahwa gharar adalah sesuatu yang majhul (tidak diketahui) akibatnya. Sedangkan menurut Sayyid Sabiq (1994:144) gharar adalah penipuan yang mana dengannya diperkirakan mengakibatkan tidak ada kerelaan jika diteliti.

\section{Dalil Haramnya Gharar}

Di dalam Quran tidak ada nash secara khusus yang mengatakan hukum ghaarar. Menurut Nafik (2009:17), Allah melarang mengambil dan memakan harta sesamanya dengan cara yang bathil kecuali dengan tukar menukar yang saling suka (ridha), seperti telah disebutkan dalam Quran surat An-nisa 29:

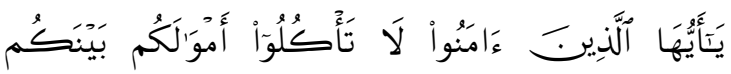

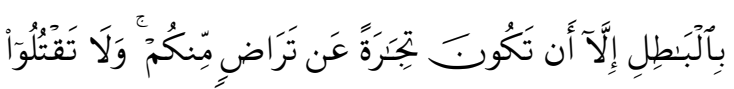

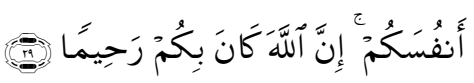
Yā ayyuha'l-lażīna āmanū lā ta'kulū amwālakum bainakum bi'l-bāṭili illā an takūna tijārotan 'an tarāẹin minkum, wa lā taqtulū anfusakum, innallāha kāna bikum rahiman.

29. Hai orang-orang yang beriman, janganlah kamu saling memakan harta sesamamu dengan jalan yang batil, kecuali dengan jalan perniagaan yang Berlaku dengan suka sama-suka di antara kamu. dan janganlah kamu membunuh dirimu. Sesungguhnya Allah adalah Maha Penyayang kepadamu.

Allah juga melarang umat manusia membawa urusan harta ke pengadilan dengan tujuan untuk dapat mengambil harta sesamanya dengan cara yang bathil walaupun mungkin disahkan oleh pengadilan atau seorang hakim. Praktik bathil ini sering terjadi hanya karena sebenarnya pihak yang memliki harta tersebut leah dalam hukum dan lemah dalam mempertahankan hartanya. Kemungkinan kejadian ini akan banyak terjadi diantara sesama manusia pada masa sekarang, maka Allah telah mengantisipasinya dengan menginatkan dan melarang perbutan yang demikian, seperti firman Allah dalam surat alBaqarah 188: 


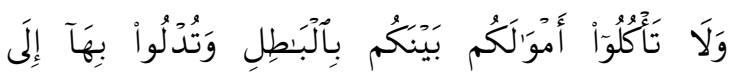

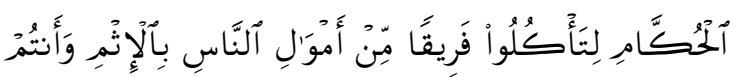

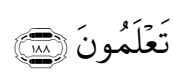

Walā ta'kuluu amwālakum bainakum

bi'l-bāṭili wa tudlū bihā ilā'l- ḥukkāmi

lita 'kulū farīqan min amwāli'n-nāsi bi'l-is̀mi

wa antum ta'lamuuna

188. dan janganlah sebahagian kamu memakan harta sebahagian yang lain di antara kamu dengan jalan yang bathil dan (janganlah) kamu membawa (urusan) harta itu kepada hakim, supaya kamu dapat memakan sebahagian daripada harta benda orang lain itu dengan (jalan berbuat) dosa, Padahal kamu mengetahui.

Dalam Quran sendiri tidak dijelaskan larangan praktik gharar, tetapi dapat diqiyaskan dari 2 ayat quran diatas yang melarang umat manusia melaksanakan akad yang merugikan salah satu pihak. Dan gharar merupakan akad yang merugikan salah satu pihak yang berakad.

Walau tidak dijumpai ayat Quran yang menjelaskan akad gharar, Rasulullah shallallahu 'alaihi wa alihi wasallam mengharamkan transaksi gharar dalam sabdanya.

Diriwayatkan oleh Imam Muslim dari Abu Hurairah radhiyallahu 'anhu :

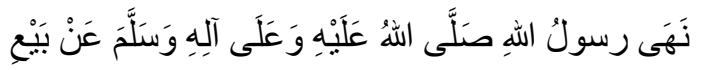

Nahā rasūlullahi shallāhu alaihi wasallama 'an bai'i'l-garari

"Rasulullah shollallahu 'alaihi wa 'ala alihi wa sallam melarang dari jual beli (dengan cara) gharar".

\section{Pembagian Gharar}

Zaroni (2007) dengan mengambil beberapa pendapat ulama menjelaskan bahwa gharar terbagi menjadi dua:

a. Gharar dalam Akad, adapun jenis gharar dalam akad adalah sebagai berikut:

1) Bai'ataini fii Ba'iah. Asy-Syaukani

menjelaskan Rasulullah SAW melarang melakukan dua kesepakatan dalam satu transaksi (bai'ataini fii ba'iah). Para ulama ahli figh sepakat dengan hadist ini secara umum dan mereka melarang seseorang untuk mengadakan dua transaksi dalam satu kesepakatan.

Diantara hadist tersebut adalah yang diriwayatkan oleh Abu Hurairah ra.

$$
\begin{aligned}
& \text { عن أبي هريرة رضي اله عنه قال: قال رسول الهه صلي } \\
& \text { الله عليه و سلم: من باع بيعتين في بيعة فله أرخصهما أو ريرة } \\
& \text { الربا (رواه أبو داود) }
\end{aligned}
$$

'an abi hurairata radhiallahu 'anhu qāla: qāla rasūllāhi shalla-llāhu 'alaihi wa sallama: man bā'a bai'ataini fị i'atin falahū arkhashuhumā aw-i-rribā.

Dari Abu Hurairah ra: telah bersabda Rasulullah SAW "Barang siapa yang menjual dua penjuaan dalam satu barang, maka baginya kerugian atau riba".

Akan tetapi dalam memahami hadist ini mereka berselisih interpretasi, 
baik dalam variasi bentuk transaksi yang bersifat mutlak ataupun yang sifatnya tidak mutlak. Beberapa interpretasi tersebut adalah :

a) Rusyd (1370 H:102) menjelaskan bahwa yang dimaksud hadits tersebut adalah jual beli 'inah, yaitu seorang yang membeli barang dengan kredit, kemudian ia jual kembali kepada orang yang menjual tadi secara tunai dengan harga yang lebih murah pada waktu itu juga.

b) Asy-Syaukani menjelaskan bahwa ada pula yang menafsirkan seseorang meminjamkan satu dinar kepada orang lain selama satu bulan dengan ketentuan dibayar satu takar gandum. Kemudian setelah datang waktu yang ditentukan dan gandum itu telah dimintanya, maka orang yang pinjam itu berkata: "Juallah gandum itu kepadaku dengan tempo pembayaran dua bulan, yang akan saya bayar dengan dua takar. Maka inilah bentuk dua macam penjualan dalam satu penjualan, karena penjualan kedua ini telah masuk dalam pada penjualan pertama.

C) Zuhaily (1997:471) menambahkan menurut Imam Syafi'। itu artinya adalah seorang penjual berkata: "Aku jual rumahku kepada engkau dengan syarat kamu jual kudamu kepadaku. d) Tafsiran yang lain adalah seorang penjual mengatakan aku jual barang seharga 1000 dengan cara tunai dan 2000 dengan tempo satu tahun, dan pembeli menjawab saya terima, tanpa menjelaskan harga mana yang ia ambil. Dan inilah yang menjadi masalah (barang tersebut diterima dengan harga mubham). Jika pembeli mengatakan aku terima barang ini dengan harga 1000 kontan atau harga 2000 dengan tempo maka jual beli tersebut akan sah.

Beberapa penafsiran di atas semuanya menunjukkan adanya unsur gharar dalam transaksi atau sighat akad terkait dengan dua kesepakatan dalam satu transaksi, dan inilah yang menjadi illat (sebab) mengapa hukumnya dilarang dilakukan dalam transaksi bisnis.

2) Bai' Urbun

Menurut Syahatah dan Adh-Dhahir (2005:154) bai' urbun adalah seseorang membeli sebuah komoditi dan sebagian pembayaran diserahkan kepada penjual sebagai uang muka (DP). Jika pembeli jadi mengambil komoditi maka uang pembayaran tersebut termasuk dalam perhitungan harga. Akan tetapi jika pembeli tidak mengambil komoditi tersebut maka uang muka tersebut menjadi milik penjual.

Berkaitan dengan bai' urbun terdapat dua hadist yang melarang dan yang membolehkan. Hadist yang melarang adalah yang diriwayatkan oleh 
Imam Malik dari seorang yang tsiqah (terpercaya) sebagaimana berikut:

$$
\begin{aligned}
& \text { عن عمرو بن شعيب عن أبيه عن جده أن رسول الله } \\
& \text { صلي الله عليه وسلم نهي عن بيع العربان. }
\end{aligned}
$$

'an 'amrū-bni syu'aibin 'an abihi 'an jaddihi anna rasūla-llāhi shalla-llahu 'alaihi wa sallama nahā 'an bai'i-l-'urban.

Dari Amr Ibn Syu'aib dari ayahnya dari kakeknya bahwasanya Rasulullah SAW melarang jual beli urbun.

$$
\text { Adapun hadist yang }
$$

membolehkan adalah yang dikeluarkan oleh Abdul Razak dalam mushanif-nya sebagaimana berikut:

$$
\begin{aligned}
& \text { عن زيد بن أسلم أنه سئل رسول الله صلي الله عليه وسلم } \\
& \text { عن العربان في البيع فأحله. }
\end{aligned}
$$

'an Zaid-i-bni Aslam annahu sa'ala RasūlaIlāhi shalla-llahu 'alaihi wa sallama 'an-il'urban fi-lbai'i fa ahallahu.

Dari Zaid Ibn Aslam bahwasanya ia telah bertanya kepada Rasulullah SAW tentang jual beli urban makaRasulullah SAW membolehkannya. (Syahatah dan AdhDhahir, 2005:155)

Meskipun terdapat dua hadist yang berbeda, namun mayoritas ulama hadist menerima dan mensahihkan hadist yang melarang jual beli urban dan menolak hadist yang membolehkannya. Kelompok ulama yang melarang adalah mazhab Hanafi, Maliki, Syafi'i, Syiah Zaidiyah, Abu Al-Khitab dari mazhab Hambali dan juga yang diriwayatkan dari Ibn Abas serta Hasan. Adapun yang membolehkan adalah Imam Ahmad dan telah diriwayatkan akan pembolehannya dari Umar serta anaknya, sebagian golongan tabi'in diantaranya adalah Ibn Sirin, Nafi' Ibn Abdul Haris, serta Zaid Ibn Aslam. (Syahatah dan Adh-Dhahir, 2005:156)

Rusyd (1370H:162) menambahkan larangan bai' urbun yang dilakukan oleh jumhur sebagaimana dijelaskan dalam kitab Bidayah al Mujtahid adalah karena adanya unsur gharar dan resiko serta memakan harta tanpa adanya 'iwadh (pengganti) yang sepadan dalam pandangan syariah. Adanya unsur gharar tersebut juga karena masing-masing pihak, baik penjual maupun pembeli tidak mengetahui apakah transaksi jual beli yang telah disepakati dapat berlangsung secara sempurna atau tidak.

3) Jual Beli Jahiliyah (Bai' Al-Hashah, Bai' Al-Mulamasah, Bai' AlMunabadzah)

Muslim (1993:139) menjelaskan, unsur gharar juga terdapat dalam tiga macam jual beli yang telah biasa dipraktekkan oleh orang-orang jahiliyah sebelum Islam. Tiga macam jual beli tersebut adalah sebagai berikut; Bai al Hashah adalah suatu transaksi bisnis dimanapenjual dan pembeli bersepakat atas jual beli suatu komoditi pada harga tertentu dengan lemparan hashah (batu kecil) yang dilakukan oleh salah satu pihak kepada pihak lain yang dijadikan pedoman atas berlangsung tidaknya transaksi tersebut, atau juga meletakan batu kecil tersebut di atas komoditi, dan juga jatuhnya batu di pihak manapun yang mengharuskan orang tersebut melakukan transaksi. 
Bai' al Mulasmasah adalah ketika kedua pihak (penjual dan pembeli) melakukan aktivitas tawar menawar atas suatu komoditi, kemudian apabila calon pembeli menyentuh komoditi tersebut (baik sengaja maupun tidak) maka dia harus membelinya baik sang pemilik komoditi tersebut rela atau tidak. Atau seorang penjual berkata kepada pembeli, "Jika ada yang menyentuh baju ini maka itu berarti anda harus membelinya dengan harga sekian, sehingga mereka menjadikan sentuhan terhadap obyek bisnis sebagai alasan untuk berlangsungnya transaksi jual beli.

Bai' al Munabadzah adalah seorang penjual berkata kepada calon pembeli, "Jika saya lemparkan sesuatu kepada anda maka transaksi jual beli harus berlangsung diantara kita", atau juga ketika pihak penjual dan calon pembeli melakukan tawar menawar komoditi kemudian penjual melemparkan sesuatu kepada calon pembeli maka ia harus membeli komoditi tersebut dan ia tidak mempunyai pilihan lain kecuali menerima transaksi tersebut, atau dengan gambaran lain seorang penjual berkata kepada calon pembeli, "Jika saya lemparkan komoditi ini kepada anda maka itu berarti saya jual komoditi ini kepada anda dengan harga sekian".

Tiga macam jual bel tersebut masuk dalam kategori jual beli gharar dan dilarang dalam Islam. Dalam sebuah hadist Nabi SAW yang riwayatnya sahih dijelaskan bahwa

$$
\text { بيع الربى رسول اله صلي الله عليه وسلم عن بيع الحصاهو }
$$

Nahā Rasulū-llāhi shalla-llāhu 'alaihi wa sallama 'an bai'i-l hashah wa bai'i-rribā Rasulullah SAW melarang jual beli hashah dan jual beli gharar. (Muslim, 1993:139)

Dalam hadist riwayat Abu Hurairah juga dijelaskan bahwa,

$$
\text { و المي رسول الهه صلي الله عليه وسلم عن بيع الملامسة }
$$

Nahā Rasulū-llāhi shalla-llāhu 'alaihi w sallama 'an bai'i-l mulāmasati wa-l muzābanati

Rasulullah SAW melarang transaksi mulamasah dan munabadzah. (Bukhori, 1992:275)

Unsur gharar yang terdapat dalam jual beli jahiliyah tersebut terletak pada shigat (kalimat) transaksinya. Hal ini dikarenakan pernyataan penjual bahwa lemparan batu kecil, sentuhan terhadap baju, dan lemparan komoditi dijadikan dasar dalam berlangsungnya kesepakatan jual beli.

4) Bai' al-Muallaq

Syahatah dan Adh-Dhahir (2005: 159) menjelaskan, bai' muallaq adalah suatu transaksi jual beli dimana keberlangsungannya tergantung pada transaksi lainnya yang disyaratkan. Keberhasilan transaksi dapat terjadi dengan mengikuti instrumen-instrumen yang ada dalam ta'liq (syarat) tersebut. Sebagai contoh adalah ketika seorang penjual mengatakan kepada calon pembeli, "Saya jual rumahku kepada anda dengan harga sekian jika si Fulan 
menjual rumahnya kepada saya". Kemudian calon pembeli menjawab, "saya terima". Kesepakatan dalam suatu transaksi jual beli semestinya tidak dapat menerima penggantungan atau pernyataan tertentu yang dijadikan ikatan atau dasar berlangsungnya transaksi. Jika hal tersebut dilakukan maka transaksi bisnis jual beli tersebut menjadi rusak, karena ada unsur gharar.

Unsur gharar pada jual beli muallaq adalah ketika kedua belah pihak (penjual dan pembeli) tidak mengetahui tercapai tidaknya masalah yang dijadikan ikatan sehingga dapat melangsungkan transaksi jual beli diantara keduanya, sebagaimana kedua belah pihak tidak mengetahui dalam kondisi yang bagaimana transaksi dapat terlaksana, karena bisa saja transaksi semacam ini terlaksana ketika keinginan pembeli atau penjual berubah seketika. Oleh karena itu jelas terdapat unsur gharar baik dari aspek terlaksana tidaknya akad, aspek waktu pelaksanaan, atau juga gharar dalam mewujudkan rasa saling rela atau tidaknya antara kedua belah pihak ketika ada syarat yang menyertainya.

Menurut mazhab Hanafi ta'lia tersebut tergolong perjudian (qimar), sehingga jual beli semacam itu tidak diperbolehkan. Sedang Ibnu Taimiyah dan Ibnu al Qayyim berpendapat lain, bahwa ta'liq diperbolehkan dalam transaksi jual beli dengan syarat kedua belah pihak tidak melihat adanya unsur gharar.

5) Bai' Al-Mudhaf
Syahatah dan Adh-Dhahir (2005: 161) menjelaskan, Bai' Mudhaf adalah kesepakatan untuk melakukan transaksi jual beli untuk waktu yang akan datang, seperti perkataan penjual kepada calon pembeli, "Saya jual rumahku kepada anda dengan harga sekian pada awal tahun depan".

Unsur gharar dalam jual beli mudhaf adalah pada aspek probabilitas dari kejadian pada beberapa kondisi, yaitu hilangnya aspek maslahah di salah satu pihak (penjual dan pembeli) serta kerelaan keduanya ketika kesepakatan jatuh tempo sesuai dengan yang disepakati, sehingga sekiranya seseorang pembeli komoditi dengan akad mudhaf dan kemudian kondisi pasar serta perekonomian berubah sehingga menyebabkan turunya harga komoditi pada waktu akad telah jatun tempo, maka dapat dipastikan pembeli tidak menyukai karena adanya selisih antara harga akad dengan kondisi real saat itu kemudian pembeli menyesal atas tindakannya.

Syahatah dan Adh-Dhahir (2005: 162) menjelaskan, jadi unsur gharar yang ada dalam bai' al mudhaf terletak pada pelaku akadnya. Ketika mereka tidak mengetahui kondisi pasar dan harga di masa yang akan datang jika dibandingkan dengan kondisi pada waktu transaksi disepakati.

6) Ketidaktahuan dalam Waktu Akad Jual beli tangguh (kredit), jika tidak dijelaskan waktu pembayarannya, maka ia termasuk jual beli gharar yang terlarang 
(Ibrahim, 476H:209). Seperti jual beli habl al-hablah, yaitu jual beli dengan sistem tangguh bayar hingga seekor unta melahirkan anaknya, atau hingga seekor unta melahirkan anak dan anak tersebut melahirkan juga anaknya. Jual beli semacam ini dikategorikan dalam jual beli gharar yang terlarang karena tidak ada kejelasan secara kongkrit dalam penentuan penangguhan pembayaran. (Syahatah dan Adh-Dhahir, 2005:180)

\section{b. Gharar dalam Obyek Akad} Madkur (1955:426) dalam hukum perjanjian Islam obyek akad dimaksudkan sebagai suatu hal yang karenanya akad dibuat dan berlaku akibat-akibat hukum akad. Obyek akad dapat berupa benda, manfaat benda, jasa atau pekerjaan, atau suatu yang lain yang tidak bertentangan dengan Syariah. Kedudukan obyek akad adalah sangat penting karena ia termasuk bagian yang harus ada (rukun) dalam hukum perjanjian Islam. Oleh karena keberadaannya sangat menentukan sah tidaknya perjanjian yang akan dilakukan, maka obyek akad harus memenuhi syarat-syarat sahnya seperti terbebas dari unsur-unsur gharar (ketidakjelasan). Ada beberapa gharar yang dapat terjadi dalam obyek akad dan akan mempengaruhi sah tidaknya suatu perjanjian:

1) Ketidakjelasan dalam Jenis Obyek Akad

Mengetahui jenis obyek akad secara jelas adalah syarat sahnya jual beli. Maka jual beli yang obyeknya tidak diketahui tidak sah hukumnya karena terdapat gharar yang banyak di dalamnya. Seperti menjual sesuatu dalam karung yang mana pembeli tidak mengetahui dengan jelas jenis barang apa yang akan ia beli.

Haroun (2000:137), namun demikian terdapat pendapat dari Mazhab Maliki yang membolehkan transaksi jual beli yang jenis obyek transaksinya tidak diketahui, jika disyaratkan kepada pembeli khiyar ru'ya (hak melihat komoditinya). Begitu juga dalam mazhab Hanafi menetapkan khiyar ru'yah tanpa dengan adanya syarat, berdasarkan hadistt berikut:

$$
\text { من اشترى شيئا لم يره فهو بالخيار إذا رأه. }
$$

Man isytarā syai'an lam yarahu fahuwa bi-l khiyāri idzā raāhu

Siapa yang membeli sesuatu yang belum ia lihat, maka ia berhak khiyar apabila telah melihat barang itu

$$
\text { Rusyd (1370H:138) ulama }
$$
Syafi'iyah mengatakan bahwa jual beli barang yang gaib tidak sah, baik barang itu disebutkan sifatnya waktu akad maupun tidak. Oleh sebab itu, menurut mereka, khiyar ru'yah tidak berlaku, karena akad itu mengandung unsur penipuan (gharar).

2) Ketidakjelasan dalam Macam Obyek Akad

Syahatah dan Adh-Dhahir (2005:167) menjelaskan bahwa gharar dalam macam obyek akad dapat menghalangi sahnya jual beli sebagaimana terjadi dalam jenis obyek akad. Tidak sahnya akad seperti ini karena mengandung unsur ketidakjelasan dalam 
obyeknya. Seperti seorang penjual berkata, "saya jual kepada anda binatang dengan harga sekian" tanpa menjelaskan binatang apa dan yang mana.

Anwar (2007:191) menambahkan oleh karena itu obyek akad disyaratkan harus ditentukan secara jelas. Dasar ketentuan ini adalah larangan Nabi SAW mengenahi jual beli kerikil (bai' al-Hashah) yang mirip judi dan biasa dilakukan oleh orang jahiliyyah. Yaitu jual beli dengan cara melemparkan batu kerikil kepada obyek jual beli, dan obyekmana yang terkena lemparan batu tersebut maka itulah jual beli yang harus dilakukan. Dalam hal ini pembeli sama sekali tidak dapat memilih apa yang seharusnya dinginkan untuk dibeli.

$$
\text { بهي رسول اله صلي الله عليه وسلم عن بيع الحصاه و }
$$

Nahā Rasulū-llāhi shalla-llāhu 'alaihi wa sallama 'an bai'i-l hashāh wa bai'i-rribā Rasulullah SAW melarang jual beli lempar krikil dan jual beli gharar. (HR. Muslim) (Muslim, 2003:139).

3) Ketidakjelasan dalam Sifat dan Karakter Obyek Transaksi

Syahatah dan Adh-Dhahir (2005:168) menjelaskan bahwa terdapat perbedaan pendapat di kalangan ulama fiqh tentang persyaratan dalam menyebutkan sifat-sifat obyek transaksi dalam jual beli, akan tetapi mayoritas ulama figh berpendapat untuk mensyaratkannya. Diantara perbedaan itu adalah; Mazhab Hanafiyah melihat, bahwa jika obyek transaksinya terlihat dalam transaksi, baik itu komoditi ataupun vang, maka tidak perlu untuk mengetahui sifat dan karakternya. Tetapi jika obyek transaksinya tidak terlihat oleh penjual dan pembeli, maka para ulama figh mazhab Hanafiyah berselisih pendapat. Sebagian mensyaratkan penjelasan sifat dan karakter obyek akad, dan sebagian tidak.

Mereka yang tidak mensyaratkan berpendapat bahwa ketidaktahuan sifat tidak menyebabkan perselisihan, disamping itu pembeli juga mempunyai hak khiyar ru'yah. Silang pendapat di atas adalah yang berkaitan dengan komoditi bukan harga, adapun tentang harga (tsaman) semua ulama sepakat untuk disebutkan sifat dan karakternya.

Sedang Ulama Mazhab Maliki mensyaratkan penyebutan sifat dan karakter baik terhadap komoditi maupun harga (tsaman). Karena tidak adanya kejelasan dalam sifat dan karakter komoditi dan harga adalah merupakan gharar yang dilarang dalam akad. (Rusyd, 1370:172) Begitu juga ulama mazhab Syafi'i mensyaratkan penyebutan sifat dan karakter komoditi dan mengatakan bahwa jual beli yang tidak jelas sifat dan karakter komoditinya hukumnya tidak sah kecuali jika pembeli diberi hak untuk melakukan khiyar ru'yah. Mazhab Hambali juga tidak membolehkan jual beli yang obyek transaksinya tidak jelas sifat dan karakternya. (Syahatah dan Adh-Dhahir, 2005:169)
4) Ketidakjelasan dalam Ukuran Obyek Transaksi 
Syahatah dan Adh-Dhahir (2005:175) menjelaskan tidak sah jual beli sesuatu yang kadarnya tidak diketahui, baik kadar komoditinya maupun kadar harga atau uangnya. Illat (alasan) hukum dilarangnya adalah karena adanya unsur gharar sebagaimana para ulama ahli figh dari mazhab Maliki dan Syafi'i dengan jelas memaparkan pendapatnya.

Rusyd (1370:156) memberikan contoh dari transaksi jual beli yang dilarang karena unsur gharar yang timbul akibat ketidaktahuan dalam kadar dan takaran obyek transaksi adalah bai' muzabanah. Yaitu jual beli barter antara buah yang masih berada di pohon dengan kurma yang telah dipanen, anggur yang masih basah dengan zabib (anggur kering), dan tanaman dengan makanan dalam takaran tertentu. Adapun illat dari pengharamannya adalah adanya unsur riba yaitu aspek penambahan dan gharar karena tidak konkritnya ukuran dan obyek atau komoditi.

5) Ketidaktahuan dalam Dzat Obyek Transaksi

Rusyd (1370:148) menjelaskan bahwa ketidaktahuan dalam zat obyek transaksi adalah bentuk dari gharar yang terlarang. Hal ini karena dzat dari komoditi tidak diketahui, walaupun jenis, macam, sifat, dan kadarnya diketahui, sehingga berpotensi untuk menimbulkan perselisihan dalam penentuan. Seperti jual pakaian atau kambing yang bermacammacam.
Ibrahim (476H:263) menjelaskan bahwa Mazhab Syafi'i, Hambali, dan Dhahiri melarang transaksi jual beli semacam ini, baik dalam kuantitas banyak maupun sedikit karena adanya unsur gharar. Sedang mazhab Maliki membolehkan baik dalam kuantitas banyak maupun sedikit dengan syarat ada khiyar bagi pembeli yang menjadikan unsur gharar tidak berpengaruh terhadap akad. Adapun mazhab Hanafiyah membolehkan dalam jumlah dua atau tiga, dan melarang yang melebihi dari tiga.

6) Ketidakmampuan dalam Penyerahan Komoditi.

Anwar (2007:191) menjelaskan bahwa kemampuan menyerahkan obyek transaksi adalah syarat sahnya dalam jual beli. Maka jika obyek transaksi tidak dapat diserahkan, secara otomatis jual belinya tidak sah karena terdapat unsur gharar (tidak jelas). Seperti menjual onta yang lari atau hilang dan tidak diketahui tempatnya.Nabi SAW melarang jual beli seperti ini karena mempertimbangkan bahwa barang itu tidak dapat dipastikan apakah akan dapat diserahkan oleh penjual atau tidak.

$$
\begin{aligned}
& \text { عن حكيم بن حزام قال سألت النبي صلى الله عليه و سلم } \\
& \text { فقلت يا رسول الله يأتيني الرجل فيسألني البيع ليس }
\end{aligned}
$$

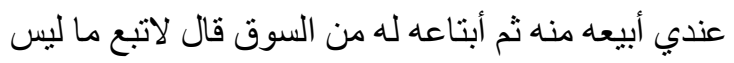

$$
\begin{aligned}
& \text { عندك (رو اه النسائ) }
\end{aligned}
$$

'an Hakìm-ibni Hizam qāla saaltu-nNabi shalla-llāhu 'alaihi wa sallama faqultu yā Rasūla-llāhi ya'tinī-rrajulu fayasaluni-I-bai'a laisa 'indi abi'uhu minhu tsumma itbaahu 
lahu mina-ssuqi qāla la tabi' mā laisa indaka (rawāhu Nasa'i)

Dari Hakim Ibn Hizam, ia berkata: AkU bertanya kepada Nabi SAW. katakU: wahai Rasulullah, seseorang datang kepadaku minta aku menjual suatu yang tidak ada padaku.Lalu aku menjualnya kepadanya, kemudian aku membelinya di pasar untuk aku serahkan kepadanya. Beliau menjawab :jangan engkau menjual barang yang tidak ada padamu.(HR. An-Nasa'i). (Abu Al-Fath, 1406H:289).

7) Melakukan Akad Atas Sesuatu yang Ma'dum (tidak nyata adanya).

Menurut Ibrahim bin Fathi (2006:16), gharar yang dapat mempengaruhi sahnya jual beli adalah tidak adanya (ma'dum) obyek transaksi. Yaitu keberadaan obyek transaksi bersifat spekulatif, mungkin ada atau mungkin tidak ada, maka jual beli seperti ini tidak sah. Seperti transaksi jual beli anak unta yang belum lahir dan buah sebelum dipanen. Seekor unta yang mengandung bisa jadi melahirkan dan ada kemungkinan tidak (keguguran), begitu juga buah terkadang berbuah dan terkadang juga tidak ada.

8) Tidak Adanya Hak Melihat atas Obyek Transaksi.

Syahatah dan Adh-Dhahir (2005:185) menjelaskan bahwa tidak adanya hak melihat atas objek transaksi yaitu jual beli yang obyeknya tidak dapat dilihat oleh salah satu dari pihak penjual atau pembeli pada saat transaksi berlangsung, baik dikarenakan komoditinya tidak ada atau ada tetapi berada dalam pembungkus. Jual beli seperti ini juga sering disebut dengan jual beli 'ainul ghaib, yaitu komoditi dimiliki penuh oleh penjual tetapi tidak dapat dilihat oleh pembeli.

Berkaitan dengan jual beli'ainul ghaib ini terdapat beberapa pendapat di kalangan ulama fiqh. Imam Syafi'i berpendapat tidak boleh menjual 'ainul ghaib secara mutlak walaupun sifat dan karakternya sudah diketahui dengan pasti. Mayoritas ulama figh memperbolehkan jika sifat dan karakternya diketahui.

Ulama bermazhab Hanafi dan Syafi'i berpendapat jual beli semacam ini tidak lazim, dan pembeli memiliki hak khiyar ru'yah, yaitu berhak membatalkan atau melanjutkan akad setelah melihat obyek transaksi. (Syahatah dan AdhDhahir, 2005:186). Menurut ulama bermazhab Maliki dan Hambali bahwa transaksi jual beli menjadi keharusan bagi sang pembeli jika ia mendapati komoditi sesuai dengan yang ia kehendaki, jika tidak sesuai maka pembeli memiliki khiyar untuk melanjutkan atau membatalkan. (Syahatah dan Adh-Dhahir, 2005:187)

\section{Industri Furnitur di Usaha Mikro}

Menurut Undang-undang No. 5 Tahun 1984 tentang Perindustrian, Industri adalah kegiatan ekonomi yang mengolah bahan mentah, bahan baku, barang setengah jadi, dan atau barang jadi menjadi barang dengan nilai yang lebih tinggi untuk penggunaannya, termasuk 
kegiatan rancangan dan perekayasaan industri.

Pengertian industri juga meliputi semua perusahaan yang mempunyai kegiatan tertentu dalam mengubah secara mekanik atau secara kimia bahanbahan organis sehingga menjadi hasil baru.

Sedangkan menurut Dumairy (1996) dalam Analisis Efisiensi Usaha Dan Implikasinya Terhadap Keberlangsungan Sektor Industri Rotan Balearjosari Kota Malang (2013) istilah industri mempunyai dua arti, pertama industri dapat diartikan berupa himpunan-himpunan perusahaan yang sejenis. Dan yang kedua, industri dapat diartikan sebagai suatu sektor ekonomi yang di dalamnya terdapat kegiatan produktif yang mengolah bahan mentah menjadi barang atau barang setengah jadi. Kegiatan pengolahan di dalamnya dapat bersifat masinal, elektrikal, atau bahkan manual. Dapat disebut sebagai sektor industri pengolahan (manufacturing), yaitu sebagai salah satu sektor produksi atau lapangan usaha dalam perhitungan pendapatan nasional menurut pendekatan produksi.

Industri furnitur tidak hanya berada di lingkup usaha menengah dan besar saja namun juga terdapat di skala usaha mikro. Saat ini telah banyak produkproduk yang dihasilkan oleh industri furnitur mikro dan cukup pesat perkembangannya. Salah satunya yang banyak dikembangkan oleh pengusaha- pengusaha baru yang menggeliat mengembangkan usahanya.

\section{METODE PENELITIAN}

Pendekatan yang digunakan dalam penelitian ini adalah pendekatan kualitatif. Menurut Yin (2011:2) pendekatan kualitatif adalah pendekatan dengan menggunakan data yang berupa kalimat tertulis atau lisan, peristiwa-peristiwa, pengetahuan atau proyek studi yang bersifat deskriptif. Pendekatan kualitatif mampu mengkomunikasikan realitas dengan penjabaran sudut pandang informan sehingga terefleksi secara nyata melalui gambaran yang aktual dan akurat tentang fakta-fakta, sifat hingga peristiwa yang diselediki.

Penelitian ini untuk menjawab rumusan masalah bagaimana praktik gharar pada kerjasama UMKM dengan pihak eksportir furnitur di kabupaten Jepara. Pertanyaan "bagaimana" lebih tepat untuk menggunakan pendekatan kualitatif karena dalam penelitian ini peneliti tidak memiliki peluang untuk melakukan kontrol terhadap obyek penelitian. Penelitian ini juga menggunakan penelitian kualitatif deskriptif. Alasan penggunaan metode penelitian kualitatif deskriptif pada penelitian ini adalah penelitian ini tidak bertujuan melakukan uji hipotesis dengan metode statistik atau ekonometri.

Strategi yang digunakan dalam penelitian ini adalah studi kasus. Menurut Yin (2011:13) studi kasus merupakan strategi yang lebih cocok bila pokok pertanyaan suatu penelitian berkenaan 
dengan pertanyaan "bagaimana" atau "mengapa", bila peneliti hanya memiliki sedikit peluang untuk mengontrol peristiwa-peristiwa yang akan diselidiki dan bilamana fokus penelitiannya terletak pada fenomena kontemporer (masa kini) di dalam konteks kehidupan nyata.

Studi kasus menurut Yin (2011:18) adalah suatu inkuiri empiris yang menyelidiki fenomena di dalam konteks kehidupan nyata, bilamana: batas-batas antara fenomena dan konteks tak tampak dengan tegas dan dimana multi sumber bukti dimanfaatkan. Strategi studi kasus memungkinkan hasil penelitian sulit untuk dimanipulasi karena dalam studi kasus peneliti hanya memiliki sedikit peluang untuk mengontrol peristiwa-peristiwa yang akan terjadi.

Lebih lanjut menurut Sukmadinata (2007:77) menyebutkan bahwa studi kasus merupakan metode untuk menghimpun dan menganalisis data berkenaan dengan suatu kasus. Sesuatu dijadikan kasus biasanya karena ada masalah, kesulitan, hambatan, penyimpangan, tetapi bisa juga sesuatu dijadikan kasus meskipun tidak ada masalah, bahkan dijadikan kasus karena keunggulan atau keberhasilannya. Yin menyebutkan terdapat lima komponen desain penelitian untuk studi kasus yaitu:

1. Pertanyaan-pertanyaan penelitian

Mengklarifikasi secara persis hakikat pertanyaan pada penelitian yang dilakukan merupakan rambu-rambu penting untuk dapat menentukan strategi penelitian yang cocok dan akan digunakan. Strategi studi kasus merupakan strategi yang paling cocok digunakan untuk tipe pertanyaan "bagaimana" seperti yang digunakan dalam penelitian ini. Pada penelitian ini menggunakan pertanyaan penelitian yaitu bagaimana praktik gharar pada hubungan usaha UMKM-eksportir furnitur di Jepara?

\section{Jenis dan Sumber Data}

Sumber data utama dalam penelitian kualitatif adalah kata-kata dan tindakan, selebihnya adalah data tambahan seperti dokumen dan lain-lain. (Moleong, 2002:112). Jenis data yang akan digunakan dalam penelitian ini adalah data primer dan data sekunder. Data primer menurut Nazir (2003:58) merupakan sumber-sumber dasar yang terdiri dari bukti-bukti atau saksi utama dari kejadian (fenomena) objek yang diteliti dan gejala yang terjadi di lapangan sedangkan data sekunder dikaitkan dengan sumber yang lain selain dokumen langsung yang menjelaskan tentang suatu gejala.

Data primer tersebut dapat diperoleh dari hasil wawancara mendalam dan observasi langsung di lapangan. Data yang dikumpulkan dengan metode wawancara memungkinkan peneliti bertatap muka langsung dengan informan untuk menggali informasi dengan lebih mendalam sehingga dapat dipertanggung jawabkan validitas datanya. Sumber data primer sebagai data utama yang diperoleh melalui wawancara mendalam dan observasi 
langsung dari informan yaitu pengusaha industri furnitur skala mikro di kabupaten Jepara. Sedangkan data sekunder berupa dokumen, yang diperoleh dari buku-buku terkait, jurnal, internet dan sumber-sumber lain yang relevan dan memiliki kaitan dengan penelitian.

Sumber dan jenis data diperoleh dengan cara sebagai berikut:

a) Key informan (informan utama)

Key informan yang dijadikan sumber data dalam penelitian ini adalah pengusaha UMKM industri furnitur di kabupaten Jepara yang terlibat langsung dalam mengelola bisnisnya dan mencapai keberlangsungan usaha pada bisnis yang telah dijalankan dengan harapan mendapat informasi tentang aktivitas kerjasma usaha dengan pihak eksportir yang telah berjalan dari sisi perkembangannya.

b) Data Penunjang

Data penunjang dalam penelitian ini merupakan data tentang kecerdasan spiritual Islam, keberlangsungan usaha serta industri furnitur skala kecil yang berasal dari buku, internet, jurnal, dan sumber-sumber lain yang memiliki kaitan dengan penelitian.

\section{Teknik Mendapatkan Informan}

Penelitian ini menggunakan teknik snowball samling dalam mendapatkan informan. Menurut Sugiyono (2012:219) snowball sampling adalah peneliti memilih orang tertentu yang dipetimbangkan akn memberikan data yang diperlukan, selanjutnya berdasar data atau informasi yang diperoleh dari sampel sebelumnya itu peneliti dapat menetapkan sampel lainnya yang dipertimbangkan akan memberikan data yang lebih lengkap.

Pertimbangan tertentu ini, misalnya informan tersebut dianggap memahami informasi sehingga akan memudahkan peneliti menjelajahi obyek atau situasi sosial yang diteliti. Dalam penelitian ini diambil beberapa informan yang mencakup bidang UMKM industri furnitur. Sejumlah informan juga mewakili wilayahwilayah di kabupaten Jepara yang datanya telah dianggap representatif untuk memberikan hasil yang menunjang bagi penelitian ini. Untuk memperoleh informan ditetapkan beberapa kriteria yang penerapannya bersifat snowball sampling dan dalam penelitian ini informan yang akan diteliti adalah sebagai berikut:

1. Pengusaha mempunyai usaha di kota Jepara.

2. Pengusaha berakad dengan pihak pemasar dengan penyerahan furnitur di awal dan waktu pelunasan vang bagi pengusaha tidak ditentukan oleh kedua pihak.

3. Pengusaha di bidang UMKM industri furnitur.

Menurut Badan Pusat Statistik (BPS), industri pengolahan (furnitur) merupakan suatu kegiatan ekonomi yang melakukan kegiatan mengubah suatu barang dasar secara mekanis, kimia, atau dengan tangan sehingga menjadi barang jadi atau setengah jadi dan atau barang yang kurang nilainya menjadi barang yang 
lebih tinggi nilainya dan sifatnya lebih dekat kepada pemakai akhir.

4. Skala usaha yang tergolong mikro.

Menurut UU No. 20 Tahun 2008 tentang Usaha Mikro, Kecil dan Menengah, yang tergolong dengan usaha skala mikro adalah memiliki hasil penjualan tahunan paling banyak Rp 300.000.000.

5. Penelitian ini akan meneliti tentang keberlangsungan usaha dari sebuah unit usaha maka dipilih sebuah unit usaha yang minimal telah bertahan tiga tahun.

\section{Teknik Pengumpulan Data}

Prosedur pengumpulan data merupakan langkah yang paling strategis dalam penelitian, karena tujuan utama dari penelitian ini adalah mendapatkan data. Tanpa mengetahui teknik pengumpulan data, maka peneliti tidak akan mendapatkan data sesuai dengan standar yang ditetapkan. (Sugiyono, 2012:224)

Penelitian ini menggunakan dua sumber data, yaitu data primer dan data sekunder. Untuk membutuhkan kedua data tersebut diperlukan langkah-langkah yang berbeda. Data primer yang digunakan sebagai data utama didapat melalui wawancara secara mendalam dengan berbagai narasumber yang dibutuhkan.

\section{Teknik Analisis Data}

Teknik analisis penelitian ini adalah pendekatan analisis kualitatif deskriptif. Analisis tersebut bertujuan menganalisis data studi kasus dengan membuat penjelasan (naratif) dan menggambarkan (deskripsi) kasus yang bersangkutan dan membuktikan proporsi teoritis yang telah dibuat. Pembahasan dilakukan dengan cara membahas bagaimana sistem operasional produk asuransi syariah dalam kesehariannya apakah telah sesuai dengan fatwa DSN atau belum. Selain itu, juga menganalisis kesesuaian sistem operasional asuransi syariah dengan Alquran dan Hadits.

Proses teknik analisis data dibagi menjadi 2 proses, yaitu sebelum dan sesudah dilapangan. Dalam proses sebelum di lapangan penulis menganalisis data dari penelitian sebelumnya atau terdahulu serta menganalisis data sekunder.

Setelah itu, dalam analisis setelah di lapangan penulis menggunakan teknik analisis lapangan model Miles dan Hubernan (Sugiyono, 2010:246). Analisis Miles dan Hubernan terdiri dari 3 tahap teknik analisis.' Tahap teknik analisis yang pertama adalah dengan menggunakan data reduksi. Dalam penelitian di lapangan, akan diperoleh data yang jumlahnya banyak. Oleh karena itu, data harus dipersempit untuk memudahkan peneliti dalam menemukan jawaban penelitian atas masalahnya. Mereduksi data yang dimaksud adalah merangkum dan memilih hal-hal yang pokok.

Tahapan teknik analisis data yang kedua adalah dengan menggunakan data display. Dalam penyajian data ini, data akan disusun menjadi pola pikiran sehingga akan lebih mudah lagi dalam pemahaman penelitian masalah. Dalam 
penyajian data, peneliti akan menyajikan datanya dalam bentuk teks naratif.

Selanjutnya, tahapan teknik analisis data yang ketiga adalah dengan menggunakan conclusion drawing atau kesimpulan dan verifikasi. Kesimpulan yang dibuat dalam tahap ini bisa menjadi jawaban atas pertanyaan yang muncul dalam penelitian pada tahap awal. Jika kesimpulan yang dikemukakan didukung oleh bukti-bukti valid, maka kesimpulan yang diambil merupakan kesimpulan yang kredibel.

\section{Teknik Validasi Data}

Validasi dari penelitian menggunakan uji kredibilitas. Uji kredibilitas data atau kepercayaan terhadap data hasil penelitian kualitatif antara lain dilakukan dengan perpanjangan pengamatan, peningkatan ketekunan dalam penelitian, triangulasi, diskusi degan teman sejawat, analisis kasus negatif, menggunakan bahan referensi, dan membercheck. Pada penelitian ini teknik uji kredibilitas yang dilakukan adalah dengan menggunakan teknik triangulasi data.

\section{HASIL DAN PEMBAHASAN}

Al-quran sangat menganjurkan kaum muslimin untuk saling bekerja sama dalam suatu kebaikan dan menolong sesama. Dalam hal kerjasama dalam perniagaan atau perdagangan, kaum muslimin harus menghindari 5 unsur yang dilarang oleh syariat Islam. Kelima unsur itu adalah maysir, gharar, riba, dhalim dan haram. Karena akan menguntungkan salah satu pihak dan merugikan buat pihak lain.

Wahbah al-Zuhaily (dalam Ghazali, 2010:55) menulis bahwa para ulama fiah mengemukakan bahwa akad itu dapat dibagi dilihat dari beberapa segi. Jika dilihat dari segi keabsahannya menurut syara', akad terbagi dua, yaitu:

a. Akad Sahih, ialah akad akad yang telah memenuhi rukun-rukun dan syarat-syaratnya. Hukum dari akad sahih ini adalah berlakunya seluruh akibat hukum yang ditimbulkan akad itu dan mengikat pada pihak-pihak yang berakad.

b. Akad ghairu sahih, yaitu akad yang terdapat kekurangan pada rukun atau syarat-syaratnya, ehingga seluruh akibat hukum akad itu tidak berlaku dan tidak mengikat phak-pihak yang berakad. Kemudian ulama Hanafiyah membagi akad yang tidak shahih ini menjadi dua macam, yaitu akad batil dan fasid. Suatu akad dikatakan batil apabila akad itu tidak memenuhi salah satu rukunnya atau ada larangan langsung dari syara'. Misalnya, objek jual beli itu tidak jelas. Atauterdapat unsur tipuan, seperti menjual ikan dalam lautan, atau salah satu pihak yang berakad tidak cakap hukum. Adapun akad fasid menurut mereka merupakan suatu akad yang pada dasarnya tidak disyariatkan, akan tetapi sifat yang diakadkan itu tidak jelas. 
Dalam penelitian ini, peneliti meneliti tentang praktik gharar pada hubungan bisnis UMKM-eksportir furnitur di Jepara. Gharar sendiri menurut jumhur ulama adalah jual beli atau transaksi yang didalamnya terdapat unsur ketidakjelasan, spekulasi, keraguan dan sejenisnya sehingga dari sebab adanya unsur-unsur tersebut mengakibatkan adanya ketidakrelaan dalam bertransaksi.

Nabi SAW bersabda

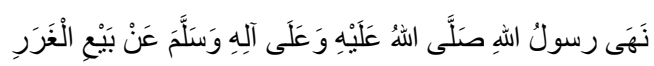
Nahā rasūlullahi shallāhu alaihi wasallama 'an bai'i'l-garari

"Rasulullah shollallahu 'alaihi wa 'ala alihi wa sallam melarang dari jual beli (dengan cara) gharar".

Adapun sebab gharar pada kerjasama UMKM-eksportir furnture di Jepara adalah kurang lengkapnya shighat akad yang dilakukan oleh kedua pihak. Setelah melakukan observasi dan wawancara tentang shighat dan kerjasama yang terjalin baik dari pihak UMKM maupun pengekspor furnitur di Jepara, terdapat ketidaksesuaian akad yang dijalankan dengan syariat Islam, dimana tidak ada kesepakatan batas waktu akhir pelunasan, sedangkan pembayaran yang disepakati adalah pembayaran secara kredit.

Berikut adalah tabel hasil wawancara dengan para informan mengenai praktik gharar yang terdapat pada kerjasama UMKM-eksportir furnitur, dimana dari peneliti memberi tanda " $\mathrm{V}$ " jika jenis gharar tersebut ditemukan pada akad dan tanda "x" jika tidak ditemukan.
Dengan catatan informan 1 dan 2 merupakan pihak pengekspor furnitur, sedangkan 3 sampai dengan 6 merupakan pelaku UMKM furnitur.

Tabel 2.

Jenis Gharar pada Shighat akad yang terdapat pada praktik hubungan bisnis UMKM Eksportir Furnitur Jepara

\begin{tabular}{|c|c|c|c|c|c|c|c|}
\hline \multicolumn{8}{|c|}{ bisnis UMKM-Eksportir furnitur Jepara } \\
\hline \multirow[b]{2}{*}{ No } & \multirow[b]{2}{*}{ Jenis Gharar pada Shighat } & \multicolumn{6}{|c|}{ Informan } \\
\hline & & 1 & 2 & 3 & 4 & 5 & 6 \\
\hline 1 & Dua akad dalam jual beli & $\mathrm{x}$ & $\mathrm{x}$ & $\mathrm{x}$ & $\mathrm{x}$ & $\mathrm{x}$ & $\mathrm{x}$ \\
\hline 2 & Jual beli Urbun & $\mathrm{x}$ & $\mathrm{x}$ & $\mathrm{x}$ & $\mathrm{x}$ & $\mathrm{x}$ & $\mathrm{x}$ \\
\hline 3 & $\begin{array}{l}\text { Jual beli Munabadzah } \\
\text { Mulamasah }\end{array}$ & $\mathrm{x}$ & $\mathrm{x}$ & $\mathrm{x}$ & $\mathrm{x}$ & $\mathrm{x}$ & $\mathrm{x}$ \\
\hline 4 & & $\mathrm{x}$ & $\mathrm{x}$ & $\mathrm{x}$ & $\mathrm{x}$ & $\mathrm{x}$ & $\mathrm{x}$ \\
\hline 5 & Aqad yang disandarkan & $\mathrm{x}$ & $\mathrm{x}$ & $\mathrm{x}$ & $\mathrm{x}$ & $\mathrm{x}$ & $\mathrm{x}$ \\
\hline 6 & $\begin{array}{l}\text { Ketidakjelasan tempo } \\
\text { pelunasan }\end{array}$ & $\mathrm{v}$ & $\mathrm{v}$ & $\mathrm{v}$ & $\mathrm{v}$ & $\mathrm{v}$ & $\mathrm{v}$ \\
\hline
\end{tabular}

Sumber : Hasil Pengolahan Data Primer

Menurut Ibrahim ibn Yusuf al-Shirazi (476 H:263), jual beli tangguh (kredit), jika tidak dijelaskan waktu pembayarannya maka ia termasuk jual beli gharar yang terlarang. Seperti jual beli habl al-habalah, yaitu jual beli dengan sistem tangguh bayar misalkan sehingga unta melahirkan anaknya, atau hingga seekor unta melahirkan anaknya dan anak tersebut dewasa dan melahirkan pula. Jual beli semacam ini dikategorikan dalam jual beli gharar yang terlarang, karena tidak ada kejelasan secara konkrit dalam penentuan penangguhan pembayaran.

\section{SIMPULAN}

1. Praktik gharar pada kerjasama antara pelaku UMKM dan perusahaan 
eksportir furnitur adalah ketidakjelasan batas waktu pelunasan pembayaran secara kredit oleh pihak perusahaan pengekspor furniture kepada pelaku UMKM furniture selaku pemasok barang kepada perusahaan.

2. Ulama berpendaat bahwa segala macam akad berunsur gharar adalah akad bathil, termasuk gharar yang berbentuk ketidakjelasan pada batas akhir pembayaran secara kredit.

\section{DAFTAR PUSTAKA}

Dumairi. 1996. Perekonomian Indonesia. Jakarta: Erlangga.

Edwin Nasution, Mustafa dkk. 2007. Pengenalan Eksklusif Ekonomi Islam. Jakarta: Kencana.

Ghazaly, Abdul Rahman dkk. 2010. Fiqh Muamalah. Jakarta: Kencana.

Hidayat, Mohammad. 2010. An Introduction to The Sharia Economic. Jakarta: Zikrul Hakim.

Moleong, J. Lexy. 2002. Metodologi Penelitian Kualitatif. Bandung: PT. Remaja Rosdakarya.

Republik Indonesia, Undang-Undang Nomor 5 Tahun 1984 Tentang Perindustrian. (Online), (diakses melalui http://bplhd.jakarta.go.id, pada 8 Maret 2014).

, Undang-Undang Nomer 9 Tahun

1995 Tentang Usaha Kecil. (Online), (diakses melalui http://sjdih.depkeu.go.id, pada 9 Maret 2014). , Undang-Undang Nomer 20 Tahun 2008 Tentang Usaha Mikro, Kecil dan Menengah. (Online), (diakses melalui http://depkop.go.id, pada 9 Maret 2014).

Sabiq, Sayyid. 1994. Fiqih Sunnah, jilid III. Kairo: Dar al-Fath li A'lam al-'Arabiy.

Sugiyono. 2012. Metode Penelitian Kualitatif, Kuantitatif dan R\&D. Bandung: Alfabeta.

Sukmadinata, Nana Shaodih. 2007. Metode Penelitian Pendidikan. Bandung: Rosdakarya.

Taimiyah, Ibnu. 2002. Majmu' al-Fatawa., juz III. Beirut: Dar al Fikri.

Yin, Robert K. 2011. Study Kasus: Desain dan Metode. Jakarta: PT. Raja Grafindo Persada.

Zaroni, Ahmad Nur. 2007. Jual Beli Gharar (Tinjaun terhadapProses dan Objek Transaksi Jual Beli). STAIN Samarinda. Online, (http://ebookbrowsee.net/7nur-zaroni-jual-beli-gharar-pdf-

d315177342)

http://www.antaranews.com/berita/41577

8/kemenperin-tingkatkan-ekspor-

furnitur-lewat-pameran-internasional, diakses 14 Juni 2014

http://www.suaramerdeka.com/vl/index. $\mathrm{php} / \mathrm{read} /$ cetak/2008/02/27/2661/Men yangga-Tiang-yang-Mulai-Goyah, diakses 14 Juni 2014 http://www. jeparakab.bps.go.id, diakses 14 Juni 2014 